\title{
ANTI-INFLAMMATORY ACTIVITY OF H1 RECEPTOR ANTAGONIST CETIRIZINE IN ANIMAL MODELS
}

Vardhamane S. H, Jeevangi Santoshkumar

1. Professor. Department of Pharmacology, MR Medical College, Gulbarga, Karnataka.

2. Associate Professor, Department of Pharmacology, MR Medical College, Gulbarga, Karnataka.

\section{CORRESPONDING AUTHOR:}

Vardhamane S. H,

Professor Pharmacology,

MR Medical College, Gulbarga,

Karnataka.

E-mail: drshvardhamane@gmail.com

ABSTRACT: AIM: The present study was designed to study anti-inflammatory activity of Cetirizine in albino rats and compare with standard drug Diclofenac. MATERIAL \& METHODS:

1. Carrageenin induced rat paw edema method (Acute inflammation): 5 animals in each group (3groups) received orally 4\% Gum acacia, Diclofenac sodium and Cetirizine respectively one hour before carrageenin injection into right paw. The rat paw edema was measured with plethysmograph after 3 hours and percentage inhibition of edema was calculated in each group. 2. Rexin pellet granuloma method (Chronic inflammation): Four rexin pellets were implanted into dorsum skin of each rat of 3 groups $(n=5)$, which include control, Diclofenac and Cetirizine respectively. The animals were treated with fixed doses of drugs once a day for 7 days including the day of implantation of pellets and on 8th day rexin pellets were removed after sacrificing animals. Rexin pellets were kept in incubator at $60^{\circ} \mathrm{C}$ overnight. Pellets were then weighed and percent inhibition of granuloma tissue was calculated. 3. Study of Mast cell counts. RESULT: Cetirizine showed significant anti-inflammatory activity both in acute and chronic animal models. CONCLUSION: Cetirizine may be used as potential drug for both acute and chronic inflammation due to its anti-inflammatory property.

KEY WORDS: Cetirizine, Diclofenac, Anti-inflammatory, Mast cell count, Rat paw edema, Rexin pellet granuloma.

INTRODUCTION: Inflammation is a complex reaction in vascularized connective tissue, which is elicited by the same exogenous and endogenous stimuli causing cell injury. The term "inflammation" is derived from the Latin literature and the Greek "Phlegmasia". Although inflammation helps in clearing infection and wound healing, both inflammation and repair have tremendous potential to cause harm ${ }^{1}$. Inflammation may contribute to a variety of disease that are not thought to be primarily due to abnormal host response .For instance, chronic inflammation may play a role in Atherosclerosis, Rheumatoid arthritis, Type -2 diabetes, Alzheimer disease and Cancer².

Histamine is a naturally occurring amine stored within the body and is capable of eliciting major changes in a variety of body functions. Histamine is stored in mast cells ${ }^{3}$. The concentration of histamine is particularly rich in tissues that contain large number of mast cells such as skin, mucosa of bronchial tree and intestinal mucosa. $\mathrm{H} 1$ receptors are found in smooth muscles, endothelial cells, adrenal medulla, heart and CNS4.

Histamine plays a major role in acute inflammation by causing an increase in vascular permeability and vasodilatation which allows general egress of white blood cells into the 
extravascular space. The potential importance of the interaction of mediators was first developed based upon the synergism between vasodilator prostaglandins and factors which increase micro vascular permeability and subsequently extended to include non-prostaglandin vasodilators. It also causes pain and itching and act as chemotactic especially for eosinophils. The role of histamine in acute inflammation associated with mast cell degranulation in nonrodent species including man where as its role in chronic inflammation is yet to be established 5 . Cetirizine is used for seasonal allergic rhinitis in children aged 2-6 years ${ }^{6}$. The antiinflammatory effect of cetirizine is similar to that of ibuprofen. The effect of cetirizine on human eosinophils from patients with allergic rhinitis was studied in vitro by Sedgwick and Busse ${ }^{7}$. Other studies, 9 also demonstrated that high concentrations $(\sim 100 \mu \mathrm{mol} / \mathrm{l})$ of cetirizine were required to achieve eosinophil inhibition in vitro. In contrast, some investigations reported significant eosinophil inhibition in vitro at cetirizine concentrations within the therapeutic range, i.e. at $0.1 \mu \mathrm{g} / \mathrm{ml}^{10}$ and cetirizine inhibition of monocytes and T cells in vitro with $0.25-2.5$ $\mu \mathrm{g} / \mathrm{ml}^{11}$.

Evidence suggests that the continual release of histamine from lung cells of asthma patients may contribute to lung tissue inflammation and remodeling and may affect lymphocytes, monocytes, basophils, epithelial cells, and macrophages by modulating the release of pro-inflammatory and immune-regulatory mediators and cytokines.12,13,14 The antiinflammatory activities of second- and third-generation H1-receptor antagonists have been evaluated in vitro. These studies have shown that many second-generation H1-receptor antagonists (considered potentially or minimally sedating) and third-generation H1-receptor antagonists (considered non-sedating) inhibit release or generation of multiple inflammatory mediators, including IL-4, IL-6, IL-8, and IL-13; PGD2; LTC4; tryptase; histamine; and the TNF- $\alpha$ induced chemokine RANTES, as well as eosinophil chemo taxis and adhesion. ${ }^{14}$

Carrageenin induced hind paw inflammation is a neutrophil-mediated acute inflammatory response that produce hind paw swelling, erythema and localized hyperthermia ${ }^{15}$. Free radicals play an important role in the pathogenesis of inflammation ${ }^{16}$.

Keeping in view of the above ideas, the present study has been undertaken to evaluate the antiinflammatory activity of newer non-sedative $\mathrm{H} 1$ receptor blocker cetirizine on the acute and chronic inflammatory models in albino rats.

MATERIALS AND METHODS: The present study was conducted in the Department of Pharmacology, Mahadevappa Rampure Medical College, Gulbarga, Karnataka, after taking permission from the Institution Ethics Committee and Animal Ethics Committee of M.R. Medical College, Gulbarga, Karnataka.

Drugs used in the study:

1. Cetirizine dihydrochloride: M/S Recon Ltd Bangalore.

2. Vehicle: Normal Saline (0.9\%) local purchase.

3. Gum Acacia: local purchase.

4. Diclofenac sodium: Pure powder obtained Biocon Pharmaceuticals, Bangalore.

5. Carrageenin: $1 \%$, INCO, Ambala.

6. Plethysmograph: INCO, Ambala.

STUDY DESIGN: Albino rats of either sex weighing 150-200g were used. Total 30 rats were selected and were divided into 3 groups of 5 each for Acute and Chronic animal models. The rats were obtained from the Central Animal House of M.R. Medical College, Gulbarga. Before starting 
the study, the animals were allowed to acclimatize to the laboratory environment for one week and they were provided with standard diet and water ad libitum as per recommendation of (CPCSEA) "Committee for the purpose of control and supervision of experiments on animals", Government of India (Reg. No.142/99, dated 11-07-1999/CPCSEA.) for laboratory animal facilities ${ }^{17,18}$.

\section{Rat Paw edema method:}

a. $\quad$ Group 1 (Control): $4 \%$ Gum Acacia, $2 \mathrm{ml} / \mathrm{kg}$.

b. Group 2 (Standard Drug): Diclofenac sodium (4.5mg/kg) in 4\% Gum Acacia.

c. $\quad$ Group 3 (Test Drug): Cetirizine $900 \mu \mathrm{g} / \mathrm{kg}$ in $4 \%$ Gum Acacia.

All the drugs were administered orally and followed by a constant volume of distilled water after each administration to ensure the entry of drug. One hour after feeding, each rat is anaesthetized with ether and under anesthesia $0.1 \mathrm{ml}$ of $1 \%$ Carrageenin is injected into subplantar region of the hind paw of the rat and the volume of paw is measured by Plethysmograph before and after injection of $1 \%$ carrageenin ${ }^{19}$. Volume of edema is recorded at the end of 3 hours after Carrageenin administration. Same procedure was adopted for rats of all the groups (Photograph 1 and Photograph 2).

The percent inhibition of edema in drug treated rats (standard and test drugs) is calculated by using the formula.

Percent inhibition $=\underline{V c-V t} \times 100$

Vt

Where,

$\mathrm{Vc}=$ Volume of paw edema in control animals

$\mathrm{Vt}=$ Volume of paw edema in drug treated animals.

The dose of the drug under study was calculated by using the dose conversion table.

Table No.1: Dose Conversion table 20.

\begin{tabular}{|l|l|l|l|l|}
\hline Drugs & $\begin{array}{l}\text { Human } \\
(70 \mathrm{~kg})\end{array}$ & $\begin{array}{l}\text { Conversion } \\
\text { factor }\end{array}$ & \multicolumn{2}{|l|}{ Dose for Rat (mg) } \\
\hline & Dose(mg/kg) & Rat & $\begin{array}{l}\text { For } \\
200 \mathrm{gms}\end{array}$ & $\begin{array}{l}\text { Per kg body weight } \\
(1000 \mathrm{gms})\end{array}$ \\
\hline Diclofenac sodium & 50 & 0.018 & 0.9 & 4.5 \\
\hline $\begin{array}{l}\text { Cetirizine } \\
\text { dihydrochloride }\end{array}$ & 10 & 0.018 & 0.18 & 0.9 \\
\hline
\end{tabular}

\section{Rexin pellet granuloma method 21 .}

Discs of equal size and weight were punched out from rexin sheet. Two such discs were stitched together with their rough surface exposed outside and rexin covered surfaces facing each other. Rexin pellets were sterilized using 70\% ethyl alcohol. Adult albino rats, 15 in number of either sex weighing about 150 to $200 \mathrm{gms}$, were selected and divided into 3 groups of 5 animals each. The first group served as a control and was given $4 \%$ Gum acacia orally. The other groups received following drugs in $4 \%$ Gum acacia suspension namely diclofenac sodium $4.5 \mathrm{mg} / \mathrm{kg}$ and cetirizine $900 \mu \mathrm{g} / \mathrm{kg}$. The dose and route of administration is same as that of rat paw edema method.

All the rats were anaesthetized with ether. The dorsal skin was shaved and applied alcohol to maintain aseptic condition. On either side of midline of dorsal skin, four small 
incisions of about $1 \mathrm{~cm}$ length were made. A curved forceps was passed through incisions to make subcutaneous pouch around it. Similarly four such pouches were made and sterilized rexin pellets were implanted into each pouch. (Photograph 3).

All the rats were treated with fixed dose of drugs (as mentioned above) once in every 24 hours for seven days including the day of implantation of pellets. The animals were provided with free access to food and water. During seven days, the rats were observed for any behavioral changes. On the 8th day, rats were sacrificed with ether anesthesia. The implanted pellets along with granulation tissue were removed. All the pellets were cleaned separately, extraneous tissue removed and dried by incubating in hot air oven at $60^{\circ} \mathrm{C}$ for $24 \mathrm{hrs}$. The pellets thus dried along with adherent granulation tissue were weighed and the weight of the granulation tissue formed was obtained by deducting the weight of rexin pellets before implantation. Then the mean weight of granulation tissue for each group was calculated. The difference in weight of granulation tissue of control and drug treated group was determined and percent inhibition was calculated by using the following formula.

Percent inhibition $=$ Wc - Wt $\times 100$

\section{Wc}

Where,

Wc $=$ Weight of pellets in control group.

$\mathrm{Wt}=$ Weight of pellets in drug treated group.

3. Study of mast cell count ${ }^{22}$ : From the control and treated groups of rats subcutaneous areolar tissue near the implanted pellet was carefully removed and thinly spread on a clean slide avoiding over stretching. The spread was fixed for 2 minutes in absolute alcohol and stained for $1 \mathrm{~min}$ in $0.1 \%$ aqueous solution of toluidine blue.

The microscopic study of subcutaneous spread collected from these animals of different groups is undertaken to find out the number of mast cells in 10 high power fields at random. Mean was calculated to find out S.D, S.E and P values and results were tabulated in Table 4.

Statistical analysis: Statistical analysis of experimental data was done by standard deviation (S.D), standard error (S.E) and P values.

RESULTS: The results obtained from the standard and test drugs are shown in Table 2, Photograp1\& 2. The percent inhibition of edema in rats treated with Diclofenac sodium, Cetirizine hydrochloride is calculated with reference to the control group. The percent inhibition of edema at the end of 3 hours with Diclofenac sodium is $61.29 \%$ whereas Cetirizine dihydrochloride is $41.93 \%$.

Table 2: Effect of standard and test drugs on carrageenin induced rat paw edema.

\begin{tabular}{|c|c|c|c|c|c|c|c|c|c|}
\hline Groups & \multicolumn{3}{|c|}{ Control Group } & \multicolumn{3}{|c|}{ Standard Group } & \multicolumn{3}{|c|}{ Test group } \\
\hline \multirow[t]{2}{*}{ Drugs } & \multicolumn{3}{|c|}{ 4\% Gum Acacia } & \multicolumn{3}{|c|}{ Diclofenac Sodium } & \multicolumn{3}{|c|}{ Cetirizine } \\
\hline & \multicolumn{3}{|c|}{ Edema Volume (ml) } & \multicolumn{3}{|c|}{ Edema Volume (ml) } & \multicolumn{3}{|c|}{ Edema Volume (ml) } \\
\hline Rat & Baseline & $\begin{array}{l}\text { At the } \\
\text { end of } \\
3\end{array}$ & $\begin{array}{l}\text { Differenc } \\
\text { e in } \\
\text { volume }\end{array}$ & Baseline & $\begin{array}{l}\text { At the } \\
\text { end of } \\
3\end{array}$ & $\begin{array}{l}\text { Difference } \\
\text { in volume } \\
(\mathrm{ml})\end{array}$ & Baseline & $\begin{array}{l}\text { At the } \\
\text { end of } \\
3\end{array}$ & $\begin{array}{l}\text { Difference } \\
\text { in volume } \\
(\mathrm{ml})\end{array}$ \\
\hline
\end{tabular}




\begin{tabular}{|c|c|c|c|c|c|c|c|c|c|}
\hline & & hours & $(\mathrm{ml})$ & & hours & & & hours & \\
\hline 1 & 1.02 & 1.30 & 0.28 & 1.04 & 1.10 & 0.06 & 0.97 & 1.12 & 0.15 \\
\hline 2 & 1.09 & 1.26 & 0.17 & 1.07 & 1.26 & 0.19 & 1.00 & 1.26 & 0.26 \\
\hline 3 & 1.02 & 1.35 & 0.33 & 1.09 & 1.22 & 0.13 & 1.08 & 1.34 & 0.26 \\
\hline 4 & 1.12 & 1.40 & 0.28 & 1.08 & 1.17 & 0.09 & 1 & 1.18 & 0.18 \\
\hline 5 & 1.01 & 1.48 & 0.47 & 1.05 & 1.19 & 0.14 & 1 & 1.13 & 0.13 \\
\hline 6 & 1.00 & 1.35 & 0.35 & 1.02 & 1.15 & 0.13 & 1 & 1.12 & 0.12 \\
\hline Mean & & & 0.31 & & & 0.12 & & & 0.18 \\
\hline $\begin{array}{l}\text { Percent } \\
\text { age } \\
\text { inhibiti } \\
\text { on of } \\
\text { edema }\end{array}$ & & & & \multicolumn{3}{|c|}{$61.29 \%$} & \multicolumn{3}{|c|}{$41.93 \%$} \\
\hline $\begin{array}{l}\text { Standar } \\
\mathrm{d} \\
\text { Deviatio } \\
\mathrm{n}\end{array}$ & \multicolumn{3}{|l|}{0.09} & \multicolumn{3}{|l|}{0.04} & \multicolumn{3}{|l|}{0.06} \\
\hline $\begin{array}{l}\text { Standar } \\
\text { d Error }\end{array}$ & \multicolumn{3}{|l|}{0.04} & \multicolumn{3}{|l|}{0.02} & \multicolumn{3}{|l|}{0.02} \\
\hline $\begin{array}{l}{ }^{*} \mathrm{p}- \\
\text { value }\end{array}$ & \multicolumn{3}{|l|}{--} & \multicolumn{3}{|c|}{$<0.001$} & \multicolumn{3}{|l|}{$>0.1$} \\
\hline
\end{tabular}

Table 3: Effect of standard drug and test drug on rexin pellet granuloma method.

\begin{tabular}{|c|c|c|c|c|c|c|}
\hline Group (n=5) & \multicolumn{2}{|c|}{ Control Group } & \multicolumn{2}{|c|}{ Standard Group } & \multicolumn{2}{|l|}{ Test Group } \\
\hline Drugs & \multicolumn{2}{|c|}{ 4\% Gum Acacia } & \multicolumn{2}{|c|}{ Diclofenac Sodium } & \multicolumn{2}{|c|}{ Cetirizine hydrochloride } \\
\hline $\begin{array}{l}\text { Rats (4 } \\
\text { pellets/ rat) }\end{array}$ & $\begin{array}{l}\text { Gain in } \\
\text { weight of } \\
\text { individual } \\
\text { rexin pellet } \\
\text { (mg) }\end{array}$ & $\begin{array}{l}\text { Mean } \\
\text { weight } \\
\text { gain } \\
(\mathrm{mg})\end{array}$ & $\begin{array}{l}\text { Gain in } \\
\text { weight of } \\
\text { individual } \\
\text { rexin pellet } \\
\text { (mg) }\end{array}$ & $\begin{array}{l}\text { Mean } \\
\text { weight } \\
\text { gain (mg) }\end{array}$ & $\begin{array}{l}\text { Gain in } \\
\text { weight of } \\
\text { individual } \\
\text { rexin pellet } \\
(\mathrm{mg})\end{array}$ & $\begin{array}{l}\text { Mean } \\
\text { weight gain } \\
(\mathrm{mg})\end{array}$ \\
\hline 1 & $18,16,14,17$ & 16.25 & $5,7,6,4$ & 5.5 & $7,8,8,9$ & 8 \\
\hline 2 & $20,17,16,14$ & 16.75 & $5,6,5,8$ & 6 & $8,7,9,7$ & 7.75 \\
\hline 3 & $20,18,15,17$ & 17.5 & $6,7,4,5$ & 5.5 & $6,8,9,7$ & 7.50 \\
\hline 4 & $18,15,16,17$ & 16.50 & $5,8,4,3$ & 5.0 & $7,6,8,9$ & 7.50 \\
\hline 5 & $20,17,16,15$ & 17.0 & $6,8,5,6$ & 6.25 & $5,6,8,9$ & 7.0 \\
\hline Total Mean & & 16.80 & & 5.65 & & 7.55 \\
\hline $\begin{array}{l}\text { Percentage } \\
\text { inhibition of } \\
\text { granulation } \\
\text { tissue }\end{array}$ & \multicolumn{2}{|l|}{--} & \multicolumn{2}{|l|}{$66.36 \%$} & \multicolumn{2}{|l|}{$50.05 \%$} \\
\hline $\begin{array}{l}\text { Standard } \\
\text { deviation }\end{array}$ & \multicolumn{2}{|l|}{0.43} & \multicolumn{2}{|l|}{0.44} & \multicolumn{2}{|l|}{0.33} \\
\hline Standard & \multicolumn{2}{|l|}{0.19} & \multicolumn{2}{|l|}{0.20} & \multicolumn{2}{|l|}{0.15} \\
\hline
\end{tabular}




\begin{tabular}{|l|l|l|l|}
\hline error & & & \\
\hline p- value & -- & $<0.001$ & $<0.001$ \\
\hline
\end{tabular}

The anti-inflammatory effect was judged by noting the percentage inhibition in granuloma formation was determined by weighing the rexin pellets 7 days after their implantation in the subcutaneous tissue are shown in Table 3. Diclofenac sodium has shown $66.36 \%$ and Cetirizine dihydrochloride $66.05 \%$ inhibition of granuloma formation. Net granuloma formation was calculated by subtracting initial weight of rexin pellet $(9.25 \mathrm{mg})$ from the weights noted ${ }^{23}$.

Table 4: Mast cell count in control, standard and test group.

\begin{tabular}{|l|l|l|l|l|l|l|l|l|l|l|l|l|l|l|}
\hline Field nos. & 1 & 2 & 3 & 4 & 5 & 6 & 7 & 8 & 9 & 10 & Mean & S.D & S.E & $\begin{array}{l}\text { P } \\
\text { value }\end{array}$ \\
\hline Control & 13 & 9 & 3 & 13 & 18 & 21 & 20 & 11 & 6 & 6 & 12.0 & 5.88 & 1.86 & -- \\
\hline $\begin{array}{l}\text { Diclofenac } \\
\text { sodium }\end{array}$ & 10 & 10 & 9 & 6 & 10 & 15 & 16 & 6 & 10 & 7 & 9.9 & 3.21 & 1.02 & $>0.10$ \\
\hline $\begin{array}{l}\text { Cetirizine } \\
\text { dihydrochloride }\end{array}$ & 5 & 7 & 12 & 7 & 8 & 8 & 11 & 5 & 4 & 5 & 7.2 & 2.52 & 0.80 & $=0.05$ \\
\hline
\end{tabular}

Mast cells were counted in 10 fields at random under high power and results were shown in Table 4. There was a marginal reduction in mast cells (Cetirizine) mean 7.2.

DISCUSSION: The principle indications for the use of second generation $\mathrm{H} 1$ receptor antagonists are in the treatment of disease with inflammatory component like allergic rhinitis, conjunctivitis, idiopathic urticarial and diseases of allergic nature like hayfever ${ }^{24}$, pollinosis ${ }^{25}$, dermographism ${ }^{26}$ and atopic eczema ${ }^{27}$. There are established facts that state that histamine play a role as a mediator of inflammation.

The edema induced is mediated by histamine and 5HT during the 1st hour after which the increased vascular permeability is maintained by kinin release up to 2.5 hours. Thereafter up to 6 hours the mediator appears to be prostaglandins ${ }^{28}$, release of which is closely associated with migration of leucocytes into the inflamed site. All the mediators appear to be dependent upon an intact complement system for their activation and release 29.

Cetirizine dihydrochloride has shown considerable anti-inflammatory activity in carrageenin induced rat paw edema. The reduction in the edema was measured at the end of 3 hours and found to be maximum.

This is the period during which prostaglandin release associated with migration of leucocytes takes place as a consequence of histamine release. There is an increase in polymorphonuclear leucocytes in carrageenin induced edema. Cetirizine might be reducing edema by decreasing the number of polymorphonuclear leucocytes which include eosinophils and neutrophils ${ }^{30}$.

The mechanism by which cetirizine produces reduction in edema might be operating at 2 stages, namely 1.Release of histamine and its effects on $\mathrm{H} 1$ receptors ${ }^{31}$.2.Eosinophil chemotaxis ${ }^{32}$, infiltration of neutrophils and platelets were inhibited.

In the chronic study (rexin pellet method), formation of granuloma was minimum with cetirizine. As granuloma represents the exudative and proliferative phases of inflammation, the drugs under study might be acting at these levels thereby reducing the migration of eosinophil's, neutrophils and platelets ${ }^{33}$. The other probable mechanism of cetirizine as an antiinflammatory activity is by release of PGE2 from monocyte and macrophages which are 
predominant cells in chronic inflammation ${ }^{34}$.One of the main substances released by the mast cells is histamine and since $\mathrm{H} 1$ receptor antagonists are being studied, a study on mast cell count has also been carried out to substantiate the results obtained in the chronic model.

The $\mathrm{H} 1$ receptor antagonist cetirizine has shown anti-inflammatory effects in animal models and it has widest therapeutic window and the lowest potential for dose limiting sedation and cognitive impairment may offer the greatest therapeutic potential for its clinical use ${ }^{35}$.

ACKNOWLEDGEMENT: My sincere thanks to Dr.Prashant Dass, Post-graduate student, Department of Pharmacology, M.R.Medical College, Gulbarga, for his help in the meticulous preparation of this manuscript.

\section{REFERENCES:}

1. Leal-Filho MB. Spinal cord injury: From inflammation to glial scar. Surg Neurol Int. 2011; 2: 112 .

2. Thomas P Bersot. Drug therapy for hypercholesterolemia and dyslipidemia. In: Laurence Burton, Bruce Chabner, Bjorn Knollman. Goodman \& Gilman's The Pharmacological Basis of Therapeutics. 12th Edition. McGraw Hill, New York 2011; 877-908.

3. Niijima-Yaoita F, Tsuchiya $\mathrm{M}$, Ohtsu $\mathrm{H}$ et al. Roles of histamine in exercise-induced fatigue: favouring endurance and protecting against exhaustion. Biol Pharm Bull. 2012;35(1):91-7.

4. Alonso N, Fernandez N, Notcovich C et al. Cross-Desensitization and Cointernalization of H1 and H2 Histamine Receptors Reveal New Insights into Histamine Signal Integration. Mol Pharmacol. 2013 Mar 5.

5. Qin L, Zhao D, Xu J,et al. The vascular permeabilizing factors histamine and serotonin induce angiogenesis through TR3/Nur77 and subsequently truncate it through thrombospondin-1. Blood. 2013 Mar 14; 121(11): 2154-2164.

6. Bruno G, Andreozzi P, Graf Uet al. Cetirizine, a second-generation H1 antagonist, modulates Rantes and MCP-1 levels in allergic rhinitis. Int J Immunopathol Pharmacol. 2002 May-Aug; 15(2): 113-118.

7. Schmi R, Walsh GM, Hartnell A, et al. Modulation of human eosinophil chemotaxis and adhesion by anti-allergic drugs in vitro. Pediatr Allergy Immunol 1993;4:13-18

8. Kyan Aung U, Hallsworth M, Haskard D, et al. The effects of cetirizine on the adhesion of human eosinophils and neutrophils to cultured human umbilical vein endothelial cells. J Allergy Clin Immunol 1992;90:270-2

9. Leprevost C, Capron M, De Vos C, et al. Inhibition of eosinophil chemotaxis by a new antiallergic compound (cetirizine). Int Arch Allergy Appl Immunol 1988;87:9-13

10. Jinquan T, Reimert CM, Deleuran B, et al. Cetirizine inhibits the in vitro and ex vivo chemotactic response of $\mathrm{T}$ lymphocytes and monocytes. J Allergy Clin Immunol 1995;95(Suppl 5):979-86

11. Triggiani M, Gentile M, Secondo A, et al. Histamine induces exocytosis and IL-6 production from human lung macrophages through interaction with $\mathrm{H} 1$ receptors. J Immunol 2001;166:4083-91

12. Marone G, Gentile M, Petraroli A, et al. Histamine-induced activation of human lung macrophages. Int Arch Allergy Immunol 2001;124:249-52 
13. Marone G, Granata F, Spadaro G, et al. Antiinflammatory effects of oxatomide. J Invest Allergol Clin Immunol 1999;9:207-14

14. Sedgwick JB, Busse WW. Inhibitory effect of cetirizine on cytokine-enhanced in vitro eosinophil survival. Ann Allergy Asthma Immunol 1997;78:581-5

15. Leung BP, Culshaw S, Gracie JA, et al. A role for IL-18 in neutrophil activation. J Immunol. 2001;167:2879-2886.

16. Sood S, Arora B, Bansal S, et al. Antioxidant, anti-inflammatory and analgesic potential of the Citrus decumana L. peel extract. Inflammopharmacol. 2009;17:267-274. doi: 10.1007/s10787-009-0015-y.

17. CPCSEA Guidelines for laboratory animal facility. Indian J Pharmacol, Special Article, Year: 2003; Volume: 35, Issue: 4 Page: 257-274.

18. Pereira S, Tettamanti M. Ahimsa and alternatives -- the concept of the 4th R. The CPCSEA in India. Altex 2005, 22(1): 3-6.

19. Brich PJ, Harrison SM, Hayes AG, et al. The non- peptide NK1 receptor antagonist ( \pm )-CP96, 345, produces antinoceptive and anti-oedema effects in the rat. $\mathrm{Br} \mathrm{J}$ Pharmacol. 1992; 105: 508-510.

20. Shymala MP, Venukumar MR, Lata MS. Anti oxidant potential of the Syzygium aromaticum (Gaertn) Linn (Clove) in rats fed with high fat diet. Indian Journal of Pharmacology 2003; 35:99-103.

21. Ghosh MN. Toxicity studies. Fundamental of Experimental Pharmacology 4th Edition, Hilton and Company, Calcutta, 2008; 178.

22. Divoux A, Moutel S, Poitou C et al. Mast cells in human adipose tissue: link with morbid obesity, inflammatory status, and diabetes. J Clin Endocrinol Metab. 2012 Sep; 97(9): E1677-85.

23. Winter CA, Porter CC. Effect of alterations in the side chain upon anti-inflammatory and liver glycogen activities of hydrocortisone esters. J Am Pharm Assoc Sci Educ. 1957;46:515-519. doi: 10.1002/jps.3030460902.

24. Mahmoud FF, Haines D, Al-Awadhi R et al. In vitro suppression of lymphocyte activation in patients with seasonal allergic rhinitis and pollen-related asthma by cetirizine or azelastine in combination with ginkgolide B or astaxanthin. Acta Physiol Hung. 2012 Jun;99(2):173-84.

25. Sastre J, Mullol J, Valero A et al. Efficacy and safety of bilastine $20 \mathrm{mg}$ compared with cetirizine $10 \mathrm{mg}$ and placebo in the treatment of perennial allergic rhinitis. Curr Med Res Opin. 2012 Jan;28(1):121-30.

26. Juhlin L, de Vos C, Rihoux JP. Inhibiting effect of cetirizine on histamine-induced and 48/80-induced wheals and flares, experimental dermographism, and cold-induced urticaria. J Allergy Clin Immunol. 1987 Oct;80(4):599-602.

27. Cook CP, Scott DW, Miller WH et al. Treatment of canine atopic dermatitis with cetirizine, a second generation antihistamine: A single-blinded, placebo-controlled study. Can Vet J. 2004 May; 45(5): 414-417.

28. Prado FC, Araldi D, Vieira AS et al. Neuronal P2X3 receptor activation is essential to the hyperalgesia induced by prostaglandins and sympathomimetic amines released during inflammation. Neuropharmacology. 2013 Apr; 67: 252-8.

29. Goicoechea de Jorge E, Caesar JJ, Malik TH et al. Dimerization of complement factor Hrelated proteins modulates complement activation in vivo. Proc Natl Acad Sci U S A. 2013 Mar 19; 110(12): 4685-90. 
30. Baroody FM, Naclerio RM. Antiallergic effects of H1-receptor antagonists. Allergy. 2000; 55 Suppl 64: 17-27.

31. Hasan S, Al Ali H, Al-Qubaisi $\mathrm{M}$ et al. Controlled-release formulation of antihistamine based on cetirizine zinc-layered hydroxide nanocomposites and its effect on histamine release from basophilic leukemia (RBL-2H3) cells. Int J Nanomedicine. 2012; 7: 3351-63.

32. Menzies-Gow A, Ying S, Phipps $S$ et al. Interactions between eotaxin, histamine and mast cells in early microvascular events associated with eosinophil recruitment to the site of allergic skin reactions in humans. Clin Exp Allergy. 2004 Aug; 34(8): 1276-82.

33. Jinquan T, Reimert CM, Deleuran B et al. Cetirizine inhibits the in vitro and ex vivo chemotactic response of T lymphocytes and monocytes. J Allergy Clin Immunol. 1995 May; 95(5 Pt 1): 979-86.

34. Zhu Y, Wang XR, Peng $C$ et al. Induction of leukotriene $B(4)$ and prostaglandin $E(2)$ release from keratinocytes by protease-activated receptor-2-activating peptide in ICR mice. Int Immunopharmacol. 2009 0ct; 9(11): 1332-6.

35. Gelfand EW, Cui ZH, Takeda K, et al. Fexofenadine modulates T-cell function, preventing allergen-induced airway inflammation and hyperresponsiveness. J Allergy Clin Immunol 2002; 110:85-95.
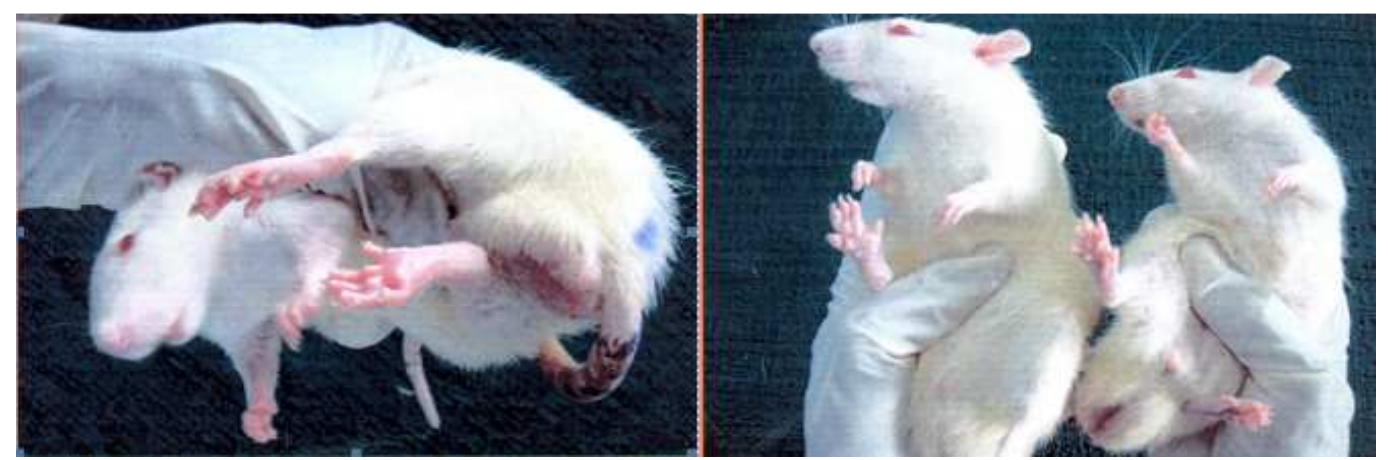

Photograph 1: Control Photograph 2: Treated

(Carrageenin induced rat paw edema) (Edema suppressed feet)

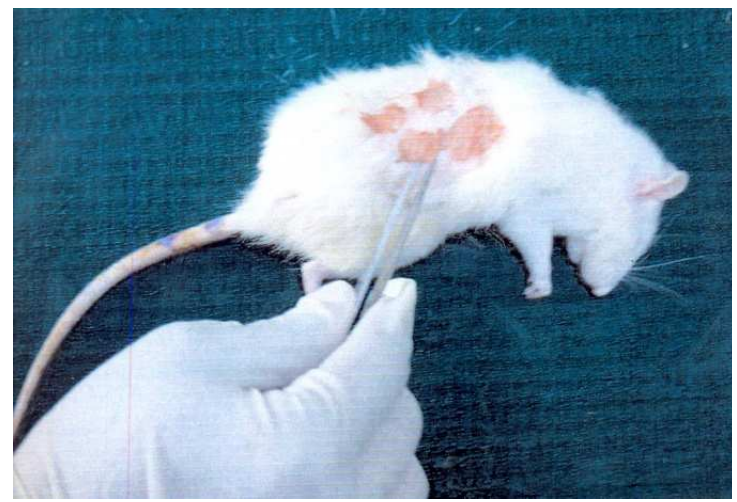

Photograph 3: Implanted rexin pellets. 


\section{ORIGINAL ARTICLE}

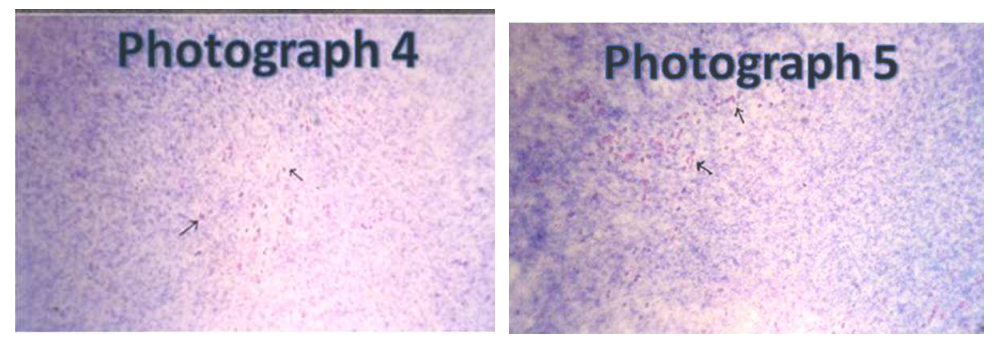

Photograph 4: Control group showing Photograph 5: Standard group (Diclofenac)

mast cells. showing marginal reduction in number mast cells.

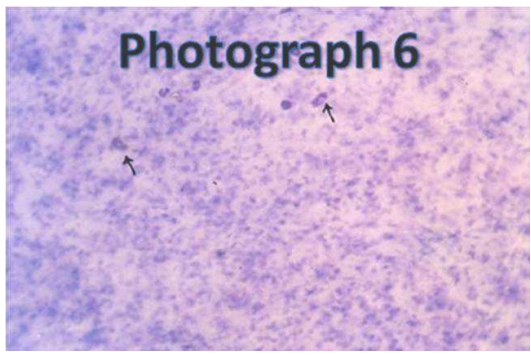

Photograph 6: Test group (Cetirizine) showing significant reduction in number of mast cells. 